\title{
Effect of Sunlight on Different Agri-Silvi-Horticulture Combination under Agroforestry System
}

\author{
Viredner Dalal, Naresh Kaushik and Rajesh Kathwal* \\ (Agronomy), RRS (Horticulture), Buria, Yamunanagar, India \\ *Corresponding author
}

\section{Keywords \\ Sunlight, Agri- Silvi-Horticulture, Agroforestry system}

\section{Article Info}

Accepted:

20 May 2019

Available Online:

10 June 2019

\section{A B S T R A C T}

A field experiment was conducted on already established silvi-horticultural system of agro-forestry at CCS H.A.U. Regional Research Station, Bawal (Rewari) during the Rabi seasons of 2011-12 and 2012-13, in which, Dalbergia sissoo and Prosopis cineraria were taken as forest tree species and Psidium guajava and Embilica officinalis as horticulture trees planted at $6 \times 6 \mathrm{~m}$ distance. Winter crops (wheat, barley and oat) were taken in association with perennial woody plants forming agri-silvi-horticultural system of agroforestry. Seeds of wheat cv. WH- 711, barley cv. BH-393 and oat cv. HJ-8 were sown in line in interspaces. Among the agri-silvi-horticulture system, guava + kehjri exhibited the highest yield. Maximum light intensity was received by crop as well as agri-silvihorticulture system during 12.00 noon to 2.00 p.m and highest being in control followed by guava + khejri. Similarly the total light intensity was found maximum in control (2108.08 lux) and guava + khejri system (563.85, 876.51, 889.47 and 1109.83) during December, January, February and March, respectively. Same trend was observed for incident solar radiation and maximum ISR was observed under guava + khejri during all the months. The grain yield of wheat, barley and fodder yield was found significantly higher under control (sole crop) and among the various agri-silvi-horticulture system, guava + khejri system resulted into higher yield i.e. 30.74, 33.84 and $559.00 \mathrm{q} / \mathrm{ha}$, respectively. Likewise the straw yield was found maximum in control and highest among the agri-silivi-horticulture system of guava + khejri i.e. 38.43 and $40.02 \mathrm{q} / \mathrm{ha}$ in wheat and barley, respectively. Total incident radiation was found positively correlated with grain, straw and fodder yield of wheat, barley and oat during all the month of growth, respectively.

\section{Introduction}

Plants are dependent upon sunlight to fuel their organic activities; insufficient sunlight stunts or prevents plant growth, while overexposure to sunlight is harmful. Plants subsist upon sunlight that they convert into chemical energy through the process of photosynthesis. The three sunlight factors that affect plant growth are the quality, intensity and duration of light. Light quality is the color or wavelength that reaches the surface of the plant. Red and blue light highly stimulate plant growth, while green light has minimal 
effect. Blue light promotes vegetative leaf growth. Red and blue light together stimulate flowering. The trees reduced photosynthetically active radiation (PAR) by 83 to $88 \%$ and soil water content by 9 to $22 \%$ in the canopy zone than those in the control plot (G. Singh 2008) Due to attenuation of solar radiation and reduced soil water availability under the canopy, there is need to study the effect of tree species on the vegetation diversity and productivity and to define appropriate technical strategies to manage these species not only to increase species diversity but also to maintain sustainable productivity in dry areas. It is extremely drought resistant, supports a higher understorey plant population than other dryland tree species and has a major role to play in agrisilvicultural and silvopastoral systems (Srivastava and Hetherington, 1991). Crop maturity was observed to be delayed by three weeks under $A$. nilotica, by 9 to 10 days under $D$. sissoo, and only by 6-7 days under $P$. cineraria and $A$. indica (Puri and Bangarwa, 1992).

\section{Materials and Methods}

The present study was carried out on 10 years old already established silvi-horticultural system of agro-forestry at Bawl, in which, 2 tree species, i.e., Shisham (Dalbergia sissoo Roxb.) and Khejri (Prosopis cineraria L.) and 2 horticultural species, i.e., guava (Psidium guajava) and Aonla (Embilica officinalis) were grown. The perennial woody plants were planted at a distance of $6 \times 6 \mathrm{~m}$ from row to row and line to line, respectively. Third components of the system, i.e., winter crops (Wheat cv. WH-711, barley cv. BH-393 and oat cv. HJ-8) were taken in association with perennial woody plants, thus forming agrisilvi-horticultural system of agro-forestry. The data was pooled for 2011-12 and 2012-13 and the homogeneity test for both the years was found non-significant. The various indices estimated in the study are given as under:-

\section{Light interception}

Light intensity was measured by 'Luxmeter' (electronic digital Luxmeter) at crop surface. The reading was taken at monthly interval under all the agri-silvi-horticulture system and in open area during the study period. The data were recorded at 8.00 a.m., 10.00 a.m., 12.00 noon, 2.00 p.m. and 4.00 p.m.

\section{Total incident radiation}

Total incident radiation was estimated with the sum of incident radiation by the sole crop during all the months of growth and here the months of growth were taken as December, January, February and March.

\section{Incident solar radiation (\%)}

It is estimated by the given formula:

ISR $(\%)=\frac{\text { Total incident radiation received by agi-horti-silviculture system }}{\text { Total incident solar radiation received by sole crop (control) }} \times 100$

\section{Correlation}

Pearson correlation coefficients were measures using the SAS 9.3 version and level of significance was taken as $\mathrm{P}=0.05$.

\section{Statistical analysis}

All the statistical procedures were carried out using SAS 9.3 version and the design used was simple randomized block design and the least significant difference (LSD) was measured with the $\mathrm{P}=0.05$ level.

\section{Results and Discussion}

The highest light intensity was observed in control during different months starting from 
December (106.76, 432.25, 672.00, 599.33 and 297.75) to March (272.00, 438.67, $640.17,684.50$ and 384.75$)$ at 8.00 a.m., 10.00 a.m., 12.00 p.m. 2.00 p.m. and at 4.00 p.m., respectively, in control (Table 1). Guava $+\quad$ Khejri horti-silviculture system significantly resulted into more light intensity available for the winter crops from December to March from 8.00 a.m. to 4.00 p.m. at the interval of two hours while the minimum in Aonla + Shisham combination. It might be due to mono layered canopy of Khejri. Highest species dominance was recorded for vegetation under $P$. cineraria. Highest average population and community biomass in the $P$. cineraria plots indicated highest facilitative effect of $P$. cineraria tree on the canopy zone vegetation. This indicated that presence of tree canopy promoted regeneration and productivity of the vegetation in the dry areas by ameliorating the adverse conditions particularly in dry areas (Frost and Mcdogald 1989; Singh et al., 2003).

\section{Total light incidence}

During all the months from December to March, the total light incidence was highly correlated with the wheat and barley grain and straw yield as well as with the oat green fodder yield (Table 4).

However, maximum correlation value of $r$ is observed in the month of January for wheat grain yield $(\mathrm{r}=0.941)$, wheat straw yield $(\mathrm{r}=$ $0.928)$, barley grain yield $(r=0.970)$, barley straw yield $(r=0.938)$ and oat green fodder yield $(r=0.886)$.

The total light incidence correlation value were again lesser in February months and higher in March month, which means to say to January and March were the most influential months for wheat and barley grain and straw yield as well as for the green fodder yield of oat (Table 2).

Yield

\section{Wheat grain and straw yield}

It is clear from the data in Table 3 that the pooled grain yield $(40.74 \mathrm{q} / \mathrm{ha})$ of sole wheat crop was significantly higher than all combinations of agri-silvi-horticulture system. Among agri-silvi-horticultural combinations, the guava based system supported significantly higher grain yield than Aonla based combination. Similar trend was observed in straw yield of wheat, where the straw yield of 49.48 quintals per hectare in control (sole wheat) was significantly higher than all other treatments of agri-silvihorticulture system.

\section{Barley grain and straw yield}

The grain yield (43.90 q/ha) of sole barley crop was significantly higher than all combinations of agri-silvi-horticulture system in Table 3. Among agri-silvi-horticulture system guava based system (guava + khejri and guava + shisham) yielded significantly higher grain yield of barley (33.84 and 32.67 q/ha) than Aonla based system (aonla + khejri and aonla + shisham) i.e. 29.84 and 29.37 $\mathrm{q} / \mathrm{ha}$, respectively, though guava + Khejri and guava + Shisham were at par. Similarly, Aonla + Shisham and Aonla + Khejri systems were at par. Similar trend was observed in straw yield of barley where the straw yield of barley, as sole crop was $52.20 \mathrm{q} / \mathrm{ha}$ which was significantly higher than other treatments. Among the agri-silvi-horticulture systems, guava + Khejri + barley significantly higher yield than Aonla based agri-silvi-horticulture system.

\section{Green fodder yield of oat}

Green fodder yield ( $\mathrm{q} / \mathrm{ha}$ ) of oat taken as sole crop were significantly higher than all other 
treatments (Table 3).

Table.1 Light intensity (lux) in winter crops under agri-silvi-horticulture system (pooled for 2011-12 and 2012-13)

\begin{tabular}{|l|c|c|c|c|c|}
\hline \multicolumn{5}{|c|}{ December } \\
\hline Treatments & $\mathbf{8}$ a.m. & $\mathbf{1 0}$ a.m. & $\mathbf{1 2}$ noon & $\mathbf{2}$ p.m. & 4 p.m. \\
\hline Control & 106.75 & 432.25 & 672.00 & 599.33 & 297.75 \\
\hline Aonla+Shisham & 39.17 & 84.67 & 144.59 & 100.25 & 46.00 \\
\hline Aonla+Khejri & 49.59 & 102.50 & 155.92 & 109.42 & 51.25 \\
\hline Guava+Shisham & 42.67 & 90.92 & 157.17 & 149.00 & 46.00 \\
\hline Guava+Khejri & 65.67 & 106.17 & 164.67 & 177.67 & 49.67 \\
\hline C.D. at 5\% & 23.00 & 44.52 & 94.08 & 56.76 & 20.04 \\
\hline & & January & & \\
\hline Control & 109.58 & 344.50 & 743.42 & 594.67 & 216.08 \\
\hline Aonla+Shisham & 51.92 & 81.67 & 258.67 & 213.58 & 85.50 \\
\hline Aonla+Khejri & 56.42 & 132.75 & 267.09 & 231.92 & 102.17 \\
\hline Guava+Shisham & 52.50 & 112.67 & 310.59 & 211.25 & 84.84 \\
\hline Guava+Khejri & 55.00 & 127.92 & 320.67 & 268.25 & 104.67 \\
\hline C.D. at 5\% & 6.77 & 35.79 & 75.39 & 33.27 & 37.15 \\
\hline & & February & & & \\
\hline Control & 181.42 & 356.97 & 688.82 & 615.75 & 263.87 \\
\hline Aonla+Shisham & 69.75 & 149.00 & 243.07 & 226.00 & 129.49 \\
\hline Aonla+Khejri & 73.12 & 161.29 & 249.15 & 232.79 & 135.59 \\
\hline Guava+Shisham & 69.72 & 161.60 & 274.74 & 232.35 & 128.75 \\
\hline Guava+Khejri & 70.55 & 165.35 & 282.40 & 238.42 & 132.75 \\
\hline C.D. at 5\% & 39.75 & 43.97 & 60.06 & 40.89 & 24.24 \\
\hline & & March & & \\
\hline Control & 272.00 & 438.67 & 640.17 & 684.50 & 384.75 \\
\hline Aonla+Shisham & 99.34 & 226.67 & 261.25 & 250.33 & 164.33 \\
\hline Aonla+Khejri & 102.75 & 231.33 & 274.92 & 263.00 & 171.67 \\
\hline Guava+Shisham & 104.50 & 233.00 & 264.67 & 281.17 & 170.17 \\
\hline Guava+Khejri & 109.17 & 241.17 & 295.42 & 289.75 & 174.33 \\
\hline C.D. at 5\% & 35.83 & 49.01 & 61.15 & 91.49 & 23.45 \\
\hline & & & & \\
\hline
\end{tabular}

Table.2 Total light intensity (lux) and ISR (\%) in winter crops under agri-silvi-horticulture system (pooled for 2011-12 and 2012-13)

\begin{tabular}{|l|c|c|c|c|c|c|c|c|}
\hline \multirow{2}{*}{ Treatments } & \multicolumn{2}{|c|}{ December } & \multicolumn{2}{c|}{ January } & \multicolumn{2}{c|}{ February } & \multicolumn{2}{c|}{ March } \\
\cline { 2 - 10 } & $\begin{array}{c}\text { Total } \\
\text { L.I }\end{array}$ & $\begin{array}{c}\text { ISR } \\
(\mathbf{\%})\end{array}$ & $\begin{array}{c}\text { Total } \\
\text { L.I }\end{array}$ & $\begin{array}{c}\text { ISR } \\
(\mathbf{\%})\end{array}$ & $\begin{array}{c}\text { Total } \\
\text { L.I }\end{array}$ & $\begin{array}{c}\text { ISR } \\
(\mathbf{\%})\end{array}$ & $\begin{array}{c}\text { Total } \\
\text { L.I } \\
(\mathbf{l u x})\end{array}$ & $\begin{array}{c}\text { ISR } \\
(\mathbf{\%})\end{array}$ \\
\hline Control & 2108.08 & - & 2108.08 & - & 2108.08 & - & 2108.08 & - \\
\hline Aonla+Shisham & 414.67 & 19.67 & 691.33 & 34.42 & 817.30 & 38.79 & 1001.92 & 41.40 \\
\hline Aonla+Khejri & 468.67 & 22.23 & 790.33 & 39.35 & 851.92 & 40.44 & 1043.67 & 43.13 \\
\hline Guava+Shisham & 485.76 & 23.04 & 771.84 & 38.43 & 867.15 & 41.16 & 1053.50 & 43.53 \\
\hline Guava+Khejri & 563.85 & 26.75 & 876.51 & 43.65 & 889.47 & 42.22 & 1109.83 & 45.86 \\
\hline
\end{tabular}


Table.3 Effects of agri-silvi-horticulture system on yield of wheat, barley and oat (pooled data for 2011-12 and 2012-13)

\begin{tabular}{|c|c|c|c|c|c|}
\hline \multirow[t]{3}{*}{ Treatments } & \multicolumn{5}{|c|}{ Yield (q/ha) } \\
\hline & \multicolumn{2}{|c|}{ Wheat } & \multicolumn{2}{|c|}{ Barley } & Oat \\
\hline & Grain & Straw & Grain & Straw & Green fodder \\
\hline Control & $40.74^{\mathrm{A}}$ & $49.48^{\mathrm{A}}$ & $43.90^{\mathrm{A}}$ & $52.50^{\mathrm{A}}$ & $635.00^{\mathrm{A}}$ \\
\hline Aonla+Shisham & $24.35^{\mathrm{C}}$ & $30.44^{\mathrm{E}}$ & $29.37^{\mathrm{C}}$ & $37.97^{\mathrm{D}}$ & $446.50^{\mathrm{E}}$ \\
\hline Aonla+Khejri & $25.66^{\mathrm{C}}$ & $31.99^{\mathrm{D}}$ & $29.84^{\mathrm{C}}$ & $38.27^{\mathrm{D}}$ & $464.00^{\mathrm{D}}$ \\
\hline Guava+Shisham & $29.65^{\mathrm{B}}$ & $37.06^{C}$ & $32.67^{\mathrm{B}}$ & $41.71^{\mathrm{C}}$ & $487.00^{C}$ \\
\hline Guava+Khejri & $30.74^{\mathrm{B}}$ & $38.43^{\mathrm{B}}$ & $33.84^{\mathrm{B}}$ & $44.02^{B}$ & $559.00^{\mathrm{B}}$ \\
\hline $\operatorname{LSD}(P=0.05)$ & 1.54 & 0.60 & 1.37 & 1.90 & 5.01 \\
\hline
\end{tabular}

Means with the same letter are not significantly different.

Table.4 Correlation between total light incidence and yield

\begin{tabular}{|l|r|r|r|r|r|}
\hline \multirow{2}{*}{$\begin{array}{l}\text { Total light } \\
\text { incidence (lux) }\end{array}$} & \multicolumn{2}{|c|}{ Wheat yield $(\mathbf{q} / \mathbf{h a})$} & & Barley $(\mathbf{q} / \mathbf{h a})$ & Oat \\
\cline { 2 - 6 } & Grain & Straw & Grain & Straw & $\begin{array}{r}\text { Green } \\
\text { fodder }\end{array}$ \\
\hline December & $0.935^{*}$ & $0.922^{*}$ & $0.966^{*}$ & $0.932^{*}$ & 0.873 \\
\hline January & $0.941^{*}$ & $0.928^{*}$ & $0.970^{*}$ & $0.938^{*}$ & $0.886^{*}$ \\
\hline February & $0.928^{*}$ & $0.913^{*}$ & $0.960^{*}$ & $0.923^{*}$ & $0.858^{*}$ \\
\hline March & $0.938^{*}$ & $0.924^{*}$ & $0.968^{*}$ & $0.934^{*}$ & 0.876 \\
\hline
\end{tabular}

*Significant at $\mathrm{P}=0.05$ level

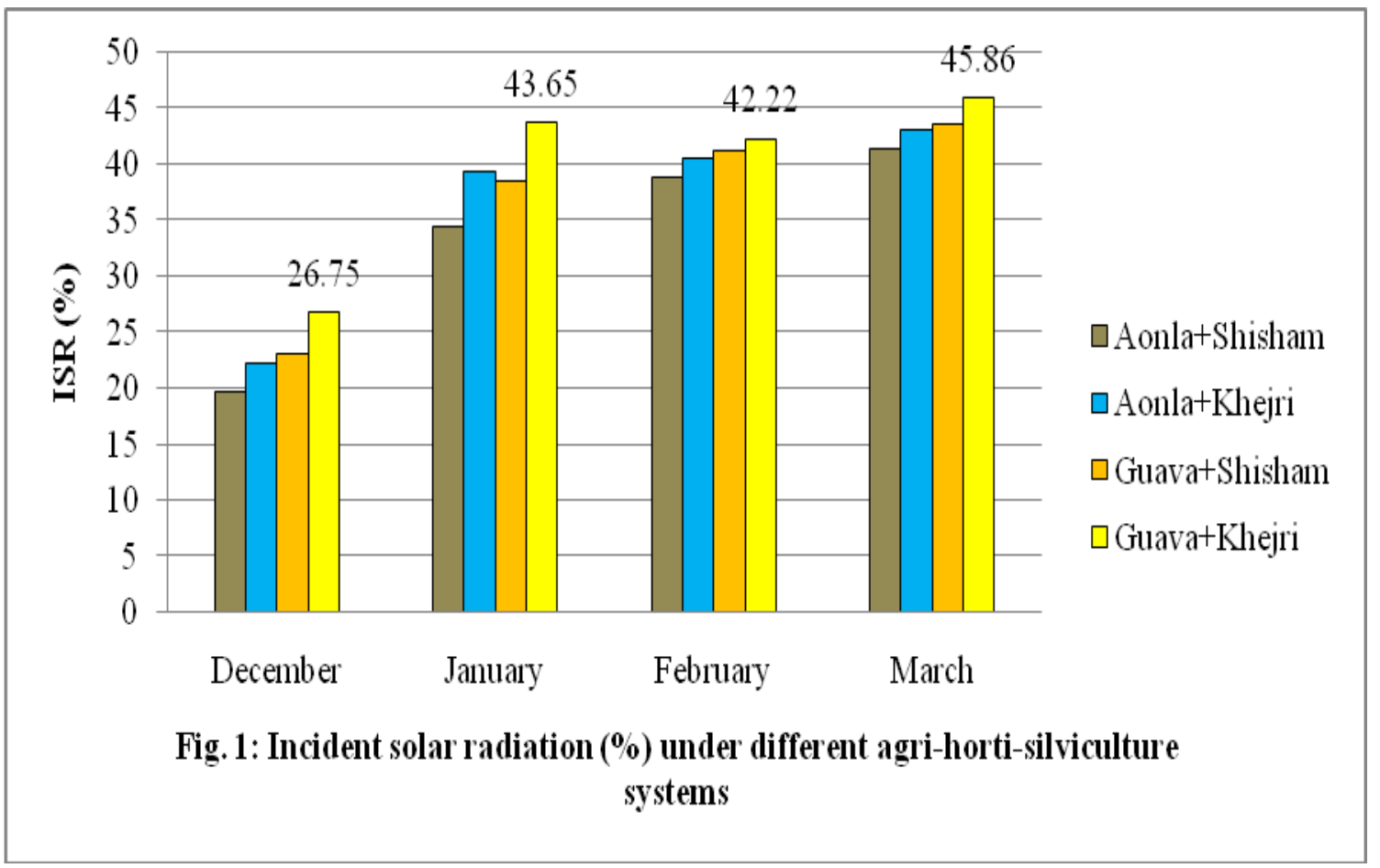


Among the agri-silvi-horticulture system, green fodder yield $(559.00 \mathrm{q} / \mathrm{ha})$ of oat in guava + Khejri combination was significantly higher than other combination. It was followed by guava + Shisham + oat $(487.00$ q/ha).

Guava based combination (guava + khejri and guava + shisham) supported significantly higher straw yield of wheat (38.43 and 37.06 q/ha, respectively) than Aonla based combination (aonla + khejri and aonla + shisham) under agri-silvi-horticulture system and same trend was observed in barley. Higher crop yield under khejri tree canopy due to improved soil fertility have been reported earlier by several workers (Aggarwal et al., 1993; Yadav et al., 2005; Singh et al., 2008). Kaushik and Kumar (2003) also observed that khejri based agri-silvi system influenced the crop growth and grain yield positively in both Kharif and Rabi seasons. Prosopis cineraria does not appear to have any adverse allelopathic effect on plants under its canopy (Goel et al., 1989). Guava also had positive impacts on crops grown under its canopy. Pateria et al., (2005) observed the maximum productivity of wheat grown under guava might be due to the fact that guava improves water holding capacity of the soil and organic carbon stock in the soil (Jalalzai et al., 2012). Singh et al., (2009) reported that root secretion of guava pushed up the yield of intercrops over its sole cropping. The results are also corroborated with the findings of Khattak et al., (1981) and Wannawong et al., (1991). Malviya and Singh (1998) also reported that guava has some ameliorative effect on chemical properties of the soil.

Based on two year average, it may be concluded that trees modified the microclimate and influenced diversity and productivity of canopy zone vegetation. The winter crops, i.e., wheat, barley and oat should be grown with guava + Khejri combination under agri-silvi-horticulture system. It moderates the micro climatic condition of crop and makes it favourable for production of the crop.

\section{Acknowledgement}

It was out great privilege to acknowledge the Department of Forestry, CCS HAU, Hisar for conducting this experiment and especially to Dr. J.C. Kaushik, Principal Scientist, Retired Principal Scientist in Forestry Department who guided us at various levels of experiment.

\section{References}

Aggarwal, R.K., Kumar, P. and Raina, P., 1993. Nutrient availability from sandy soils underneath Prosopis cineraria (Linn. Macbride) compared to adjacent open site in an arid environment. Indian Forester, 119: 321-325.

Datta, M. and Singh, N.P., 2007. Growth characteristics of multipurpose tree species, crop productivity and soil properties in Agro-forestry system under subtropical humid climate in India. Journal of Forestry Research, 18(4): 261-270.

Frost, W.E. and Mcdogald, N.K., 1989. Tree canopy effects on herbaceous production of annual rangeland during drought. Journal of Range Management 42: 281-283.

Goel, U., Saxena, D.B. and Kumar, B., 1989. Comparative study of allelopathy as exhibited by Prosopis juliflora Swartz and Prosopis cineraria (L.) Druce. Journal of Chemical Ecology, 15: 591600.

Jalalzai, S.W., Ramakrishna-Parama, V.R. and Munawery, A., 2012. Soil physio- 
chemical properties and organic carbon stocks as influenced by different land use system of alfisol. Mysore Journal of Agricultural Sciences, 46(4): 738-744.

Puri, S. and Bangarwa K. S., 1992. Effects of trees on the yield of irrigated wheat crop in semi-arid regions Agroforestry Systems 20 (3): 229-241

Singh, G., N. Bala, T. R. Rathod and Chouhan, S. 2003. Effect of adult neighbours on regeneration and performance of surface vegetation in shifting dune of Indian desert for the control of sand drift. Environmental Conservation 30: 353-363.

Singh, G., Rathod, T.R., Mutha, S., Upadhyaya S. and Bala N., 2008. Impact of different tree species canopy on diversity and productivity of understory vegetation in Indian desert. Tropical Ecology 49(1): 13-23.

Singh, G., Rathod, T.R., Mutha, S.,
Upadhyaya, S. and Bala, N., 2008. Impact of different tree species canopy on diversity and productivity of under canopy vegetation in Indian desert. Tropical Ecology, 49(1): 13-23.

Srivastava, J. P. and Hetherington, J. C., 1991. Khejri (Prosopis cineraria): a tree for the arid and semi-arid zones of Rajasthan. International Tree Crops Journal 7 (1-2): 1-16.

Wannawong, S., Belt, G.H. and Mcketta, C.W., 1991. Benefit: cost analysis of selected agro-forestry systems in northeastern Thailand. Agro-forestry Systems, 16(1): 83-94.

Yadav, R.S., Yadav, B.L., Chhippa, B.R. and Keshwa, G.L., 2005. Nutrient removal and yield of wheat (Triticum aestivum L.) as influenced by different tree species in agro-forestry under semi-arid condition of Rajasthan. Indian Journal of Agro-forestry, 7(1): 21-24.

\section{How to cite this article:}

Viredner Dalal, Naresh Kaushik and Rajesh Kathwal. 2019. Effect of Sunlight on Different Agri-Silvi-Horticulture Combination under Agroforestry System. Int.J.Curr.Microbiol.App.Sci. 8(06): 2732-2738. doi: https://doi.org/10.20546/ijcmas.2019.806.328 